\title{
Antecedents of Technology Adoption in Learning Environments: Evidence from MENA Higher Education
}

\author{
Maha Mourad $^{1} \&$ Rania S. Hussein ${ }^{2}$ \\ ${ }^{1}$ School of Business, The American University in Cairo, Egypt \\ ${ }^{2}$ School of Business, The American University in Cairo and Cairo University, Egypt \\ Correspondance: Rania S. Hussein, The American University in Cairo and Cairo University, Egypt.
}

Received: September 9, 2018

Accepted: October 5, 2018 Online Published: November 24, 2018

doi:10.5539/ijms.v10n4p51

URL: https://doi.org/10.5539/ijms.v10n4p51

\begin{abstract}
Focusing on the emerging economy in the Middle East and North Africa (MENA) region, this paper seeks to examine and test the antecedents of technological innovation adoption in the higher education sector and its impact on the learning environment. This research focuses on the adoption of technological education tools by students, who are the main adopter of technology considered here. A rich model encompassing technology factors, university based factors as well as consumer based factors, is adopted in this research. The model is developed based on three sources that are: Roger's (2003) innovation adoption model, The Resource -based view of the firm (RBV) and previous literature. The adopted conceptual model highlighted that the adoption decision is based on a combination of perceived attributes of the educational technology, inter-organization factors and consumer factors. Data was collected from a convenient sample of students from three types of universities; public, private and foreign. Thus, the model is testified drawing on the results of empirical work conducted on three top ranked universities in Egypt. It should be noted that Egypt is selected as the country of analysis as it presents the largest educational sector in the MENA region in terms of capacity and structure. Data collection resulted in 300 usable questionnaires. The research model has been tested using Structural Equation Modelling (SEM). Results indicate that attributes of the innovation, institutional factors and market orientation policy were found to have a significant direct impact on technology adoption by students in universities. These findings lead to managerial implications focusing on managing students' expectations and enhancing the learning environment within the HEIs in the MENA region. The contribution of this research is both theoretical and empirical. At the theoretical level, this research presents a distinctive model that encompasses a wide diversity of factors (technology based, institution based and consumer based) factors to study a rapidly changing topic like technology adoption in an important sector which is the higher education sector. At the empirical level, this research covers three key universities in Egypt and presents important implications on factors to be focused on in order to increase the level of technology use in the higher education sector.
\end{abstract}

Keywords: higher education, educational technology, innovation adoption, MENA region

\section{Overview}

The importance of the higher education sector in the MENA region cannot be underestimated as aside from being a sizable industry, it also prepares future decision makers who will shape the economy and the international role of the region (Getz, Siegfried, \& Anderson, 1997). That is why it is extremely important to study different aspects on education management especially how Higher Education Institutions (HEIs) in the MENA region are working on satisfying the needs of their stakeholders in general and students in specific. Managing students' expectations is proven to be one of the main factors that influence students' satisfaction especially when it is relating to the learning environment. Based on the literature review, the learning environment could be enhanced through different approaches one of them is the adoption of education technology tools as a means of interaction within the HEIs (Levin, Stephan, \& Winkler, 2012). In spite of this fact, few studies had focused on the adoption of technology tools within (MENA) higher education sector. This research attempts to explore antecedents of technology tools adoption by students in the higher education sector. The adopted conceptual model highlighted that the adoption decision is based on a combination of factors namely; perceived attributes of the educational technology, inter-organization factors and consumer factors. The model is testified drawing on the results of empirical work conducted among three top ranked universities in 
Egypt. It should be noted that Egypt was selected as the context of research as it presents the larger educational sector in the MENA region in terms of capacity and structure. The findings lead to managerial implications focusing on managing students' expectations and enhancing the learning environment within the HEIs in the MENA region.

\section{Education Technology Tools in Higher Education}

Technological innovations are now considered crucial for the survival and growth of organizations especially in developing countries (Bagherinejad, 2006; Drennan \& Coll-Kennedy, 2003). This is the case in the HEIs especially since choosing the education service by potential consumers, namely students, is associated with higher risk (Laroche, Bergeron, \& Goutaland, 2003; Mitchell, 1999). In order to reduce the perceived risk, most of the HEIs utilize technological innovations to enhance service performance and learning environment (Jiménez-Jiménez \& Sanz-Valle, 2011). Higher Education technology normally "comprises the new application methods and tools that enhance the educational system" (Mourad, 2010, p. 605). Adoption of these technology driven tools is extremely beneficial for delivering the learning material as they provide room for an interactive teaching method that is both flexible and efficient. Education technology applications such as blackboard, moodle, clud, edmodo etc, have altered the educational landscape by transforming it into a more mobile and continuous process. These applications increase connectivity between students and their professors. Students are able to share their knowledge, which improves their skills (Zahao, Englert, \& Chen, 2000). In addition, using innovative technologies within educational institutes stimulates engagement and participation of students to share questions and feedback, which ultimately improves the quality of education that they receive (Dessart, Veloutsou \& Morgan-Thomas, 2015). Hence, this enables the HEI to manage the students' expectations and enhance the learning environment. However, in several emerging markets within the MENA region this is not always the case. In spite of the visible benefits of education technology tools in higher education, there are still a number of challenges facing the adoption within higher education institutions.

\section{Conceptual Framework and Hypotheses Development}

The adopted conceptual framework highlighted that the adoption decision of education technology is based on a combination of perceived attributes of the educational technology, inter-organization factors and consumer factors (Hussein \& Mourad, 2014). This model was tested on a B2B context focusing on the adoption of the faculty and administrators to the technological innovations. The model was adopted since it represents an integration of different frameworks that are modified and tested within the higher education industry in the MENA region.

The adopted framework was modified to focus on the factors that affect the students' willingness to utilize technology in higher education. These elements have been divided in three main categories; innovation attributes, university factors and consumer characteristics. The framework encompasses elements that have been empirically proven to have an impact on innovation adoption (Urban \& Hauser, 1980; Gupta \& Rogers, 1991; Rogers, 2003; von Hippel, 2005; Zhu \& Kraemer, 2005; Straub, 2009; Baltaci-Goktalay \& Ocak, 2006; Goldsmith \& Witt, 2005; Gupta \& Rogers, 1991; Lyons \& Henderson, 2005; von Hippel, 2005; Takada \& Jain, 1991; Morrison et al., 2000). Some attributes that have been mentioned in the literature review were eliminated from this paper because past empirical studies have proven their irrelevance to the Higher Education service. To illustrate, trialability was excluded from the innovation attributes because it has shown mixed results in past empirical results (Black et al., 2001; Hassan et al., 2010; Mourad, 2010). Moreover, gender, age and income have been excluded from consumer characteristics because empirical work in the past has shown that they don't have a direct impact on the adoption of technology within the Egyptian Higher Education (Mourad, 2010).

The first set of independent variables in the model represents the perceived characteristics of the education technology tools. Theses characteristics are relative advantages, compatibility, complexity and observability. The positive relation between these characteristics and the adoption of innovation was empirically tested in different industries (Premkumar \& Roberts, 1999; Hassan, Mourad, \& Tolba, 2010; Black et al., 2001; Frambach et al., 1998; Houghton \& Winklhofer, 2002) as well as in the higher education sector (Hussein \& Mourad, 2015; Mourad, 2010; Beatty et al., 2001). In this research, it is assumed that if students find that the education technology tools used in their university enhance the learning experience (relative advantage), are consistent with their needs (compatibility), are simple to use (complexity) and enhance the social interaction and the sharing of ideas (observability), they will be willing to change the currently used methods and adopt the new technology. Previous literature found significant relationships between innovation attributes and the speed with which adoption occurs (Hussein \& Mourad, 2014; Siuking et al., 2016; Davide et al., 2018). Based on the above, it is expected that: 


\section{H1 There is a positive relationship between relative advantage and innovation adoption.}

\section{H2 There is a positive relationship between compatibility and innovation adoption.}

H3 There is negative relationship between complexity and innovation adoption.

\section{H4 There is positive relationship exists between observability and innovation adoption.}

The second set of independent variables is relating to the university based factors that influence the adoption of technology in higher education, which are: top management support, faculty and staff IT knowledge and market orientation policy. These factors are institutional factors that are based on the resource based view of the firm (RBV). These factors have been found in literature to be important factors that impact technology adoption and use in organizations. It was found in previous studies that innovation adoption in any institution is affected by the level of IT knowledge of its staff/employees, the support given to this new innovation by management and how enthusiastic management is to that innovation, as well as the market orientation of this university in terms of being focused on and aligned with market dynamics and changes. These three factors were seen to be particularly relevant to the context of this study, which is the adoption of the education technology tools by students. That is to say that it was found in the literature that it is important to start by assessing the diffusion speed of innovative technologies within the university in order to evaluate students' adoption of this technology and its impact of the learning environment (Levin, Stephan, \& Winkler, 2012). Previous research findings provide evidence on the significance these factors on technology adoption (Eggers \& Aseem, 2018; Irena et al., 2013; Jason et al., 2016) Thus, it is expected that:

\section{H5 There is a positive relationship between staff IT knowledge and innovation adoption.}

H6 There is a positive relationship between a university's market orientation and innovation adoption.

\section{H7 There is a positive relationship between top management support and innovation adoption.}

The last set of independent variables focuses on personality traits that are expected to affect consumers' decisions to adopt or not adopt technology. This research focuses on students as the main adopter and recipient of technology. Students are thus perceived as the customers adopting innovation in this context. Thus, it was important to capture the consumer based factors that affects adoption of technology. The personality traits used in this research are based on the comprehensive technology readiness index (TRI) which encompasses a diverse array of consumer based factors like risk tasking, innovativeness, need for interaction and others (Kleignen, de Ruyter, \& Wetzels, 2004). This model focuses on three main influential dimensions namely; optimism, customer innovativeness, and need for interaction that have proven to be significant factors in various contexts based on previous research findings (Venkatapparao et al., 2016; Vijayendra et al., 2015; Liljander et al., 2006; Curran \& Meuter, 2005). Based on the above, it is expected that:

\section{H8 There is a positive relationship between consumer characteristics and innovation adoption.}

\section{Higher Education Sector in MENA}

The Higher Education industry in Egypt constitutes an intriguing context for empirical research as a representative case from the MENA region. Egypt has been selected because of the growing trend in its market that aims to reform the Higher Education service to encompass private, public and foreign institutions. That is to say that Egypt represents a justified sample of the MENA region due to its capacity and reform program.

The players in the Egyptian higher education market are public, foreign, and private universities. It should be noted that there is a growing gap between the different universities when it comes to adoption of technological innovations and offering quality education (McCann, 2014). Hence, in Egypt foreign and private universities are more likely to adopt educational technology as a tool to enhance the learning environment. This discrepancy can be attributed to the differences in the resources within the universities in Egypt (Mourad, 2011). This fact is worth investigation and comparison for the sake of understanding the factors influencing students' adoption of educational technology and their impact on the learning environment within the Egyptian Higher Education market.

\section{Methodology}

This research follows a quantitative approach whereby a wide scale survey has been used to test the proposed model. The empirical study was conducted on a convenient sample of Egyptian students enrolled in public, private and foreign universities to represent the whole higher education market with its diversities in Egypt. Data were collected using drop and collect questionnaires from each of the three designated university over a period of two months. Over this period of data collection, 300 usable questionnaires were generated. The sample consisted of undergraduate students from three different universities in Egypt. The key constructs were measured 
using established scales that have been tested in previous researches. The wording of the items has been modified to fit the current context. New items were added when needed. All elements were measured on a five-point Likert scale, from 1: "strongly agree" to 5: "strongly disagree". When using a positivist perspective and examining a group of hypotheses in a structural equation model, a significant fundamental theory is essential (Dibbern, 2004). Accordingly, all hypotheses are well established and validated in existing studies and researches.

The research model has been tested with Structural equation modelling (SEM) using LISREL 8.7. SEM was used for various reasons. First, using SEM technique provides highly competent estimation techniques as it is composed of several separate multiple regression equations estimated concurrently where frameworks could be represented by a summated scale (Hair et al., 2010). Also SEM differentiates between unobserved theoretical constructs and imperfect empirical measures and it is covariance-based rather than variance-based (Steenkamp \& Baumgartner, 1991).

A confirmatory factor analysis (CFA) was first conducted. The model fit is assessed in terms of four indices: comparative fit index (CFI), goodness-of-fit index (GFI), root mean square error of approximation (RMSEA) and the consistent Akaike information criterion (CAIC). A model is considered to be satisfactory if CFI $>0.95$, GFI $>0.90$ and RMSEA $<0.06$ (Hair et al., 2010). CAIC has no cut-off values; instead, a smaller value implies better fit.

The results of the CFA indicate a good model fit $\left(\mathrm{x}^{2}=394\right.$; CFI $=0.97$; GFI $=0.91$; RMSEA=0.056; CAIC $=$ 1.726.49). In addition to the model fit, reliability, convergent validity and discriminant validity of the scales were all tested. Reliability was examined on the basis of CR and AVE. A scale is said to be reliable if CR $>0.70$ and AVE $>0.50$ (Hair et al., 2010). The CRs and AVEs of all scales turned out to be more than the cut-off values. Convergent validity is tested by construct and indicator reliability. Fornell and Larcker (1981) indicate that adequate convergent validity measures should contain less than $50 \%$ error variance, that is, an average variance extracted higher than 50\% (Ping, 2004). As a result, evidence of convergent validity is supported for all the constructs as the loadings are significant and higher than 0.7. Discriminant validity is the extent to which an item does not relate to the measures of other constructs. Discriminant validity is achieved if the square root of the AVE is greater than the correlation coefficients (Hair et al., 2010). Discriminant validity was measured using several approaches suggested within the literature. One way is that if the Chi-square is significant, this would suggest that correlation is not one and hence would imply that constructs are distinct (Anderson \& Gerbing, 1988; Steenkamp \& Van Trijp, 1991; Ping, 2004). This process would be repeated for each pair of constructs within the measurement model for exogenous constructs. Suggest support for discriminant validity. The average variance extracted for each construct is greater than the recommended threshold of 0.5 (Fornell \& Larcker, 1981). Overall, the evidence of a good model fit, reliability, convergent validity, and discriminant validity indicates that the measurement model was appropriate for testing the structural model.

\section{Results}

The explanatory power of structural model has been evaluated in addition to the review of the measurement model. There were ten factors included in the final model. These factors represented the research model's three independent variables. In line with expectations, the core attributes indicated good exploratory power. The variance in the outcome variable has been reasonably explained by the model with $75 \%$ of the variance in the technology adoption variable. Table (1) shows the means, standard deviation (SD), composite reliability (CR) and Average Variance extracted (AVE) of the estimated factors.

Table 1. Estimated factor correlation matrix from the measurement model

\begin{tabular}{lllllllllllllll}
\hline & Mean & SD & CR & AVE & 1 & 2 & 3 & 4 & 5 & 6 & 7 & 8 & 9 & 10 \\
\hline RELADV & 5.5102 & 1.46865 & 0.893 & 0.677 & 1 & & & & & & & & & \\
COMPX & 5.1520 & 1.64678 & 0.676 & 0.511 & 0.50 & 1 & & & & & & & \\
COMPT & 5.9169 & 1.18567 & 0.753 & 0.603 & 0.40 & 0.49 & 1 & & & & & \\
OBSERV & 5.6724 & 1.25520 & 0.726 & 0.570 & 0.24 & 0.44 & 0.53 & 1 & & & & \\
STIT & 4.7252 & 2.02709 & 0.768 & 0.543 & 0.03 & 0.28 & 0.21 & 0.17 & 1 & & & & \\
MKTOR & 3.9498 & 1.72176 & 0.771 & 0.628 & 0.11 & 0.42 & 0.18 & 0.13 & 0.69 & 1 & & & \\
MGTSUP & 4.3386 & 1.75946 & 0.866 & 0.763 & 0.12 & 0.34 & 0.23 & 0.15 & 0.78 & 0.89 & 1 & & \\
OPTM & 5.8918 & 1.22413 & 0.716 & 0.560 & 0.22 & 0.26 & 0.35 & 0.41 & 0.07 & 0.00 & -0.03 & 1 & \\
CSTINV & 4.5799 & 1.39599 & 0.750 & 0.607 & 0.13 & 0.26 & 0.33 & 0.20 & 0.02 & 0.22 & 0.11 & 0.36 & 1 \\
NDINT & 5.4890 & 1.30518 & 0.755 & 0.607 & 0.08 & 0.30 & 0.31 & 0.33 & -0.03 & 0.05 & -0.05 & 0.58 & 0.21 & 1 \\
\hline
\end{tabular}

RELADV=relative advantage, COMPX=complexity, COMPT=compatibility, OBSERV=observability, STIT=staff IT knowledge, $\mathrm{MKTOR}=$ market orientation, MGTSUP=management support, $\mathrm{OPTM}=$ optimism, $C S T I N V=$ innovativeness, NDINT=need for interaction; 
Value on Diagonal is the square root of AVE.

Based on the model's complete standardized solution, all the innovation characteristics have been found significant. The estimated results shown in table (2) indicate that the relative advantage of the innovation and the compatibility of the innovation have a slightly higher coefficient value $(0.191$ and 0.22$)$ in comparison with the complexity and observability characteristics (0.11 and 0.096). Hence, the complexity and observability should be interpreted with care. The direction of the relation between the innovation characteristics and the Innovation adoption is positive with the exception of complexity. The negative relation between complexity and technology adoption indicates that the more difficult using WEBCT/blackboard is perceived by students, the less likely they are to use it. This is in line with previous research results. Therefore, H1, H2, H3 and H4 are all supported according to the results shown above.

Table 2. T-statistics and standardized path coefficients for hypothesized paths in the structural model

\begin{tabular}{lllll}
\hline Hypothesis & Construct & Estimate & T-sat & Significant/ Not Significant \\
\hline H1 & Relative Advantage $\rightarrow$ tech adoption & 0.191 & $1.71^{* * *}$ & $\sqrt{ }$ \\
H2 & Compatibility $\rightarrow$ tech adoption & 0.22 & $2.2^{* *}$ & $\sqrt{ }$ \\
H3 & Complexity $\rightarrow$ tech adoption & -0.11 & $-1.22^{* * *}$ & $\sqrt{ }$ \\
H4 & Observability $\rightarrow$ tech adoption & 0.096 & $1.14^{* * *}$ & $\sqrt{ }$ \\
H5 & Staff IT knowledge $\rightarrow$ tech adoption & 0.069 & 0.58 & - \\
H6 & Market Orientation $\rightarrow$ tech adoption & 0.64 & $2.18^{* *}$ & $\sqrt{ }$ \\
H7 & Top Management Support $\rightarrow$ tech adoption & 1.31 & $4.14^{*}$ & $\sqrt{ }$ \\
H8 & Consumer Characteristics $\rightarrow$ tech adoption & & & - \\
& H8a Optimisim & 0.059 & 0.61 & \\
& H8b Customer Innovation & 0.034 & 0.44 & \\
& H8c Need for interaction & 0.061 & 0.68 & \\
\hline
\end{tabular}

Note. This table shows the t-statistics and standardized path coefficients for hypothesized paths in the structural model. *, ${ }^{*}, * * *$ indicates significance at the $0.01,0.05$, and 0.1 levels respectively, $\sqrt{ }$ indicates that hypothesis is supported and - indicates that hypothesis is not supported.

Concerning the university characteristics, a strong significant support was found to the positive effect of market orientation and top management support on the adoption of the technology in the higher education market. Top management support shows a stronger significant influence compared to market orientation (1.31 and 0.64). On the other hand, faculty and staff IT knowledge turned out to be insignificant $(\mathrm{t}=0.58)$. This hypothesis is thus not supported. This result might be due to the context of the empirical study, which is education institutions, and hence the applicants did not examine the possibility of having staff without IT knowledge, as it should be a default in any higher education institute. As a result, $\mathrm{H} 6$ and $\mathrm{H} 7$ are supported, whereas $\mathrm{H} 5$ is rejected.

As for consumer characteristics, researchers found that their influence on technology adoption is not significant and thus hypothesis $\mathrm{H} 8 \mathrm{a}, \mathrm{H} 8 \mathrm{~b}$ and $\mathrm{H} 8 \mathrm{c}$ are all not supported. That is to say that it is clear from table 2 that optimism, customer innovation and need for interaction have no significant impact on the adoption of the technology in the higher education market and hence these hypotheses will be rejected. This might indicate that consumers' characteristics may be more relevant when different levels of adoption are being studied rather than for only adoption vs. non-adoption decision as is the case in this research. It might indicate that these characteristics become more important when there is room to study the different levels of WEBCT/blackboard use that students can undertake based on their very characteristics such as those proposed here.

Finally, since the majority of the attributes relating to innovation and university characteristics have a significant impact on technology adoption in the Higher Education market, we consider the proposed conceptual model to be useful in explaining the adoption of technology in the higher education market in Egypt.

\section{Conclusion and Managerial Implications}

This research fills a gap in the MENA higher education literature by providing an empirical construct for the adoption of innovative technologies in higher education stemming from the positive transformational impact that these innovations have on students and educational institutions. The main contribution of this paper is its empirical evidence. It helped determine the antecedents of technology adoption within the Higher Education service in the MENA region. The attributes that can influence students' adoption of technological innovation in MENA higher education have been the focus of this study. The paper also gave an overview of how the adoption of technological innovations can result in the transformation of students. The Higher Education service has been transformed by technology especially as technological innovations continue to grow. Having examined the 
different factors that affect the adoption of technology innovation in Higher Education service it is important to highlight how this technological adoption can be integrated with the Higher Education institution policy in order to maximize its benefits.

Based on the analysis of the factors that facilitate the adoption of technology particularly in the MENA Higher Education sector, a set of policy recommendations can be extracted to help with the management of these technological innovations. As shown in the analysis, there is a strong explanatory power of the innovation's perceived attributes and university characteristics including, market orientation and top management support on technology adoption in the higher education. This indicates that when more students understand the benefits of using technologies like WEBCT/blackboard for enhancing their learning, they will become more eager to adopt them (Hussein \& Mourad, 2014). Therefore, it is recommended that universities provide orientations to students to help them gain a better understanding of the added value from using these technologies. However, it is worth noting that when the technological innovation in question is considered to be of high complexity by students, they would become less likely to adopt it. Therefore, higher education institutions should provide training sessions to the students in order to explain the various features of the technology and to make it easier for them to use.

Further findings show that the higher the management support is for utilizing new technologies in delivering education and the more market oriented the education institution is, the higher the chances that students will adopt the technological innovation. It can hence be concluded that university policies towards adopting innovative tools for delivering education have a substantial effect on students' adoption rate of these technologies. According to Berthon et al (2005), when using new technologies, customers often become in control of these tools and shape how they should be used and sometimes the usage scope exceeds that of the intended developer's purpose. Accordingly, it is necessary for students to have easy access to innovative educational technologies because students can transform these tools to enhance their educational benefits and learning development.

Hence, it is recommended that universities' top management issue policies foster an innovation-stimulating culture that is open to raising awareness about new technologies as well as experimenting with them in order to maximize the benefits. "New technology can help us do old things in a better way" (Johannessen, 1994). According to Johannessen, having easy access to information can "precipitate customer - induced innovation" (1994). That is to say that the true transformational impact that innovative technologies have on students and universities lies in their ability to facilitate communication and share information and that is why universities' managements should ensure their adoption.

Any research has its own limitations. The research has addressed a very specific context, which might have made the findings harder to generalize on a wider scope. Accordingly, future studies can involve a cross-cultural analysis by utilizing the framework addressed in this paper to other countries in MENA region. Creating a comparison between the research findings in Egypt and other countries will reveal if the same set of elements are considered equally important and whether the structure can be generalized across several countries. Future contributions can attempt modifying the framework used in this paper to encompass the educational institution and the students' angles. This would help to clarify which attributes have an influence on the initial trigger for the universities' adoption of innovative technologies.

\section{References}

Anderson, C., \& Gerbing, W. (1988). Structural Equation Modeling in Practice: A Review and Recommended Two-Step Approach. Psychological Bulletin, 103(3), 411-423. https://doi.org/10.1037/0033-2909.103.3.411

Bagherinejad, J. (2006). Cultivating technological innovations in Middle Eastern countries. Cross Cultural Management, 13(4), 361-380. https://doi.org/10.1108/13527600610713440

Baltaci-Goktalay, S., \& Ocak, M. A. (2006). Faculty Adoption of Online Technology in Higher Education. The Turkish Online Journal of Educational Technology (TOJET), 5(4), 37-43.

Beatty, R., Shim, J., \& Jones, M. (2001). Factors influencing corporate web site adoption: a time-based assessment. Information and Management, 38, 337-354. https://doi.org/10.1016/S0378-7206(00)00064-1

Berthon, P. R., Hulbert, J. M., \& Pitt, L. F. (2005). Consuming Technology: Why Marketers Sometimes Get It Wrong. California Management Review, 88(1), 110-128.

Bharati, P., \& Chaudhury, A. (2006). Studying the current status of technology adoption. Communications of the ACM, 49(10), 88-93. https://doi.org/10.1145/1164394.1164400 
Black, N., Lockett, A., Winklhofer, H., \& Ennew, C. (2001). The adoption of Internet financial services: a qualitative study. International Journal of Retail and Distribution Management, 29(8), 390-398. https://doi.org/10.1108/09590550110397033

Bruque, S., \& Moyano, J. (2007). Organizational determinants of information technology adoption and implementation in SMEs: The case of family and cooperative firms. Technovation, 27, 241-253. https://doi.org/10.1016/j.technovation.2006.12.003

Curran, J., \& Meuter, M. (2005). Self-service technology adoption: comparing three technologies. Journal of Services Marketing, 19(2), 103-113. https://doi.org/10.1108/08876040510591411

Damanpour, F., \& Schneider, M. (2009). Characteristics of Innovation and Innovation Adoption in Public Organizations: Assessing the Role of Managers. Journal of Public Administration Research \& Theory, 19(3), 495-522. https://doi.org/10.1093/jopart/mun021

Davide, A., Marianna, G., Massimiliano, M., \& Francesco, N. (2018). Backing Environmental innovations through information technology adoption. Empirical analysis of innovation related complementarity in firms. Technological and Economic Development of Economy, 24(1), 141-163. https://doi.org/10.3846/20294913.2015.1124151

Dessart, L., Veloutsou, C., \& Morgan-Thomas, A. (2015). Consumer engagement in online brand communities: a social media perspective. Journal of Product \& Brand Management, 24(1), 28-42. https://doi.org/10.1108/JPBM-06-2014-0635

Dibbern, J. (2004). The sourcing of Application software services: Empirical Evidence of Cultural, Industry and Functional Differences. Physica, Heidelberg. https://doi.org/10.1007/978-3-7908-2704-0

Drennan, J., \& Coll-Kennedy, J. R. M. (2003). The relationship between Internet use and perceived performance in retail and professional service firms. Journal of Services Marketing, 17(3), 295-311. https://doi.org/10.1108/08876040310474837

Eggers, J., \& Aseem, K. (2018). Motivation and ability? A behavioral perspective on the pursuit of radical invention in multi-technology incumbents. Academy of Management Journal, 61(1), 67-93. https://doi.org/10.5465/amj.2015.1123

El Mahdy, M., \& Mourad, M. (2008). Higher Education in Africa: Internationalization Dimensions. Co-published by the Association of African Universities (AAU) and the Centre for International Higher Education (CIHE), Boston College, USA.

Fornell, C., \& Larcker, F. (1981). Evaluating Structural Equation Models with unobservable variables and measurement error. Journal of Marketing Research, 48, 39-50. https://doi.org/10.2307/3151312

Frambach, R., Barkema, H., Nooteboom, B., \& Wedel, M. (1998). Adoption of a service innovation in the business market: an empirical test of supply-side variables. Journal of Business Research, 41, 161-174. https://doi.org/10.1016/S0148-2963(97)00005-2

Getz, M., Siegfried, J., \& Anderson, K. (1997). Adoption of innovations in higher education. The Quarterly Review of Economics and Finance, 37(3), 605-631. https://doi.org/10.1016/S1062-9769(97)90013-2

Goode, S., \& Stevens, K. (2000). An analysis of the business characteristics of adopters and non-adopters of World Wide Web technology. Information Technology and Management, 1, 129-154. https://doi.org/10.1023/A:1019112722593

Hair, J., Black, W., Babin, B., \& Anderson, R. (2010). Multivariate Data Analysis (7th ed.). New Jersey: Prentice Hall.

Hassan, S., Mourad, M., \& Tolba, A. (2010). Conceptualizing the Influence of Lead Users and Opinion Leaders on Accelerating the Rate of Innovation Diffusion. International Journal of Technology Marketing, 5(3), 203-218. https://doi.org/10.1504/IJTMKT.2010.039033

Houghton, K., \& Winklhofer, H. (2002). Internet adoption in exporting SMEs: development of a conceptual model. American Marketing Association, Conference Proceedings, Chicago 13, p. 504.

Hussein, R., \& Mourad, M. (2014). The adoption of technological innovations in a B2B context: an empirical study on the higher education industry in Egypt. Journal of Business \& Industrial Marketing, 29(6), 525-545. https://doi.org/10.1108/JBIM-07-2013-0155

Irena, D., Jean-Philippe, T., \& Yann, T. (2013). Social Innovation in Emerging Economies: A resource based 
view perspective. Strategic Change, 22(7/8), 503-510. https://doi.org/10.1002/jsc.1954

Jason, L., Yuandi, W., \& Lutao, N. (2016). How do dynamic capabilities transform external technologies into firms' renewed technological resources? A mediation model. Asia Pacific Journal of Management, 33(4), 1009-1036. https://doi.org/10.1007/s10490-016-9469-9

Jiménez-Jiménez, D., \& Sanz-Valle, R. (2011). Innovation, organizational learning, and performance. Journal of Business Research, 64(4), 408-417. https://doi.org/10.1016/j.jbusres.2010.09.010

Johannessen, J. (1994). Information Technology and Innovation. Information Management \& Computer Security, 2(2), 4-9. https://doi.org/10.1108/09685229410059532

Kleijnen, M., de Ruyter, K., \& Wetzels, M. (2004). Consumer adoption of wireless services: discovering the rules while playing the game. Journal of Interactive Marketing, 18(2), 51-61. https://doi.org/10.1002/dir.20002

Lai, S., Lai, F., \& Lowry, P. B. (2016). Technology evaluation and imitation: do they have differential of dichotomous effect on ERP adoption and assimilation in China? Journal of Management Information Systems, 33(4), 1209-1251. https://doi.org/10.1080/07421222.2016.1267534

Laroche, M., Bergeron, J., \& Goutaland, C. (2003). How intangibility affects perceived risk: The moderating role of knowledge and involvement. Journal of Services Marketing, 17(2), 122-140. https://doi.org/10.1108/08876040310467907

Levin, S., Stephan, P., \& Winkler, A. (2012). Innovation in academe: the diffusion of information technologies. Applied Economics, 44(14), 1765-1782. https://doi.org/10.1080/00036846.2011.554375

Liljander, V., Gillberg, F., Gummerus, J., \& Riel, A. (2006). Technology readiness and the evaluation and adoption of self-service technologies. Journal of Retailing and Consumer Services, 13, 177-191. https://doi.org/10.1016/j.jretconser.2005.08.004

McCann, P. (2014). Keys to the City: How Economics, Institutions, Social Interaction, and Politics Shape Development. Journal of Regional Science, 54(3), 524-527. https://doi.org/10.1111/jors.12128

Mitchell, V. (1999). Consumer perceived risk: Conceptualizations and models. European Journal of Marketing, 33(1/2). https://doi.org/10.1108/03090569910249229

Mourad, M. (2010). Students' Adoption of Online Education Service: Empirical Evidence from the Higher Education (HE) Market. Online Information Review, 34(4), 604-617. https://doi.org/10.1108/14684521011073007

Mourad, M. (2011). Role of Brand Related Factors in influencing Students' choice in Higher Education (HE) Market. Int. J. of Management in Education, 5(2/3), 258-270. https://doi.org/10.1504/IJMIE.2011.039488

Premkumar, G., \& Roberts, M. (1999). Adoption of new information technologies in rural small businesses. Omega International Journal of Management Science, 27, 467-484. https://doi.org/10.1016/S0305-0483(98)00071-1

Rogers, E. M. (2003). Diffusion of Innovations (5th ed.). New York: The Free Press.

Steenkamp, M., \& van Trijp, M. (1991). The use of LISREL in validating marketing constructs. International Journal of Research in Marketing, 8, 283-299. https://doi.org/10.1016/0167-8116(91)90027-5

Sultan, F., \& Chan, L. (2000). The adoption of new technology: the case of object-oriented computing in software companies. IEEE transactions on Engineering Management, 47(1), 106-126. https://doi.org/10.1109/17.820730

Tolba, A., \& Mourad, M. (2011). Individual and cultural factors affecting diffusion of innovation. Journal of International Business \& Cultural Studies, 5, 1-16.

Venkatapparao, M., Juan, M., \& Kevin, E. (2016). Consumer Technology readiness and E service quality in E-tailing: what is the impact on predicting online purchasing? Journal of Internet Commerce, 15(4), 311-333. https://doi.org/10.1080/15332861.2016.1237232

Vijayendra, G., \& Renuka, G. (2015). Technology readiness index of E-banking users: some measurement and sample survey evidence. IUP Journal of Bank Management, 14(4), 43-58. 


\section{Copyrights}

Copyright for this article is retained by the author, with first publication rights granted to the journal.

This is an open-access article distributed under the terms and conditions of the Creative Commons Attribution license (http://creativecommons.org/licenses/by/4.0/). 